\title{
THE PECULIARITIES OF THE DEVELOPMENT OF ECONOMIC THOUGHT IN LITHUANIA (SIXTEENTH-NINETEENTH CENTURIES)
}

\author{
Egidija Laumenskaite
}

ABSTRACT Economic thought in Lithuania has comparatively deep historical roots and some special achievements to its credit. The establishment of the Department of Political Economy at the University of Vilnius in 1803 was the first such high recognition of the physiocrats' concept in the history of economic science. The reasons for physiocracy to appear as a syllabus subject at Vilnius University were rooted not only in the specific character of the country's economy and educational system, but also in the ideological prehistory of the discipline. The turn of the sixteenth and seventeenth centuries marked the first period of vigorous development in economic thought in Lithuania and coincided with the development of economic ideas at Vilnius University, established in 1579. Rapid changes in economic life and the widespread Reformation movement in the mid-sixteenth century gave birth to active debates on social and economic issues. At that time the Grand Duchy of Lithuania was not merely following the development of economic ideas of the West (which was the fact later, especially with the upsurge in the economic thought in the twentieth century), but also disputing them (although the scope of this polemic was noticeably slender) and looking for solutions to the country's keenest economic problems. The economic ideas of Jan Abramowicz, Marcin Smiglecki and others are worth consideration in the context of the development of European economic thought as a whole. The educational reforms at Vilnius University at the end of the eighteenth century (from Vilnius Academy, managed by Jesuits, to a more open educational institution) gave a birth to a new upsurge of economic thought in Lithuania. Vilnius University adopted the new discipline of Political Economy. Professors Hieronim Stroynowski, Jan Waszkewicz, and Michat Oczapowski started developing various courses in economics. However, after the Uprising of 1831 the University of Vilnius was closed down and further development of economic thought was restricted for almost a century. The unsteady evolution of economic thought in Lithuania in the period under review is connected with the country's general economic and political development. 
The establishment of the Department of Political Economy at Vilnius University in 1803 is a fact worth noting. Moreover, it comes as a surprise to some to hear that it was in Vilnius that the discipline was recognised as an official part of a university curriculum for the first time. Nobody doubts that at that time economic thought was at a more advanced level in Great Britain or France, but some transformation process in the educational system of the University of Vilnius (after it was reformed from the former Jesuit Academy to become a more open educational institution) provided good soil for sowing new academic seed. Most European universities still had departments of cameralism for the studies of economic issues; the ideas of political economy mainly remained introduced in courses of moral philosophy. The establishment of the Department of Political Economy at Vilnius University meant the recognition of the earlier teaching of physiocracy. ${ }^{1}$ What then are the reasons for such a high recognition of political economy in the Lithuanian educational system?

There were several reasons why physiocracy appeared as a discipline taught at Vilnius University. Firstly, close relations existed between members of the Lithuanian nobility, the rector of the University, Hieronim Stroynowski, and French physiocrats. As we know, sometimes personal factors play a crucial role in historical events or decisions. Lithuanian noblemen such as Chancellor Joachimas Chreptavičius and Bishop Ignas J. Masalskis of Vilnius maintained personal relations with the French physiocrats Nicolas Baudeau, and François Quesnay de Saint-Germain, who used to visit Lithuania and Poland. Pierre Samuel du Pont de Nemours even took part in the work of the Educational Board whilst revising the curriculum at the University of Vilnius.

Secondly, the ideas of the physiocrats proved acceptable to theologians. The social vision of physiocracy was strongly influenced by natural law and religion. The doctrine of natural law and scholasticism still had strong traditions at Vilnius University. Ever since the University was founded (1579) professors and lecturers developed economic ideas in their studies and lectures. Most authors fought for free trade, the development of local agriculture and estate harmony. To some extent this was a precondition for the development

${ }^{1}$ Physiocracy as an economic theory was most popular in France in the second half of the eighteenth century. Physiocrats expressed the interests of the new class of bourgeois landlords and considered land to be the only source of production. 
of physiocratic ideas. Thirdly, the upper class of landlords in such an agricultural country as Lithuania felt more sympathy for the teachings of the physiocrats than they did for the economic ideas of mercantilists or Adam Smith. Many progressive authors in Lithuania at the turn of the sixteenth and seventeenth centuries even opposed the ideas of mercantilism.

It is worth reviewing previous developments in economic thought in Lithuania in order to understand better the reasons for the acknowledgement given to the ideas of physiocracy and to see the rise of the economic thought as a phenomenon connected directly with the upturn of the general economic development of the Grand Duchy of Lithuania.

In Lithuanian history we can distinguish three periods of vigorous development in economic thought: the turn of the sixteenth and seventeenth centuries, the late-eighteenth and early-nineteenth centuries, when the Department of Political Economy was established at Vilnius University, and the first half of the twentieth century. In the second half of the twentieth century economic thought in this country followed in the footsteps of Soviet economic ideas. Only in the last decade of the twentieth century did the free development of economic thought gain a strong impetus.

The first period (c. 1579-1700) has been investigated only scarcely so far. Only the economic creed of Marcin Smiglecki (1564?-1618) has been analysed partly by some Lithuanian and Polish researchers. ${ }^{2}$ The social ideas of the representatives of Reformation in Lithuania have been studies, mainly by Ingè Lukšaitè. ${ }^{3}$ A broader analysis of the economic thought of this period in Lithuania has been carried out by Egidija Laumenskaite. ${ }^{4}$

The second period of the upsurge of economic thought in Lithuania (in the late-eighteenth and early-nineteenth centuries) has

${ }^{2}$ Lietuvos publicistai valstiečiu klausimu XVI a. pab.-XVII a. pirmoje puseje, ed. I. Lukšaite, Acta Historica Lituanica, vol.12 (1976); K. Jablonskis, Lietuviu kultūra ir jos veikejai (Vilnius, 1973); Z. Gargas, 'Marcin Smiglecki i jego traktat o lichwie', Przewodnik nauki i literatury, rocz. 25 (1897); E. Lipinski, Historia polskiej mysli spolezcno-ekonomicznej do konca XVIII wieku (Wroclaw, 1975).

${ }^{3}$ I. Lukšaitè, Radikalioji Reformacijos kryptis Lietuvoje (Vilnius, 1980); eadem, 'Adomas Rasijus - Lietuvos kultūros veikèjas ir jo traktatai', LTSR MAD, A. ser., vol. 1-106 (1989).

${ }^{4}$ E. Laumenskaitè, Ekonominè mintis ir jos kürëjai Lietuvoje XVI-XVII a. (Vilnius, 1995). 
been studied by Algirdas Makarevičius ${ }^{5}$ and has been reflected in other works on the development of social and economic ideas.

In the current article we overview these two periods of the rise of economic thought in the Grand Duchy of Lithuania and its connection with the country's economic development. Moreover, we will point out some links between the economic ideas of these two rather distant periods and assess these ideas in the context of the European economic thought.

The end of the sixteenth century and the beginning of the seventeenth century marked a time when economic thought in Lithuania was not merely following the development of economic ideas of the West (which later became the case), but also entering into dispute with them, even though the scope of such polemic was noticeably small.

The University of Vilnius, as established by Jesuits, became an intellectual fortress with a clearly expressed purpose: to overcome the spread of Protestantism in Lithuania. The rather significant Reformation movement in Lithuania in the middle sixteenth century induced a pronounced rise in social thought. For the first time free labour force requirements were formulated, and the Arians even demanded a complete abolition of serfdom.

Perhaps it is not correct to perceive the Reformation movement as a decisive factor of changes in society and production, although such approach to it as to the force that accelerated the development of capitalism is rather frequent. Max Weber was one of the first supporters of this concept, which has received also harsh criticism. George Robertson, with the aid of numerous examples, has shown that bourgeois economic ideas had been developed gradually by both Protestant and Catholic ideologists. The developing economic relations imposed changes also on the views of Catholic scholastics themselves, forcing them to revise their mediaeval postulates. These tendencies were pronounced in Lithuania in the first period of boosted economic thought at the turn of the sixteenth and seventeenth centuries.

What were the first works in Lithuania to pave the road for the development of economic thought? The first treatises on economic problems were published late in the sixteenth century. The book [On

5 A. Makarevičius, Ekonominè mintis Lietuvoje feodalinio ūkio irimo ir kapitalistiniu santykiu formavimosi salygomis, doctoral dissertation, University of Vilnius, 1962). 
Usury and Three Best Contracts: Ransom, Land Rent and Merchants' Company] ${ }^{6}$ written by Marcin Smiglecki, professor of canon law at the Vilnius Academy, was republished as many as eight times before the mid-eighteenth century. It is a typical reflection of the second wave of scholastic economic thought. Second came scholastics, a product of the post-Reformation period imbibed with certain ideas of modern times, still kept in touch with the medieval scholastic tradition; this is why the views of many of thinkers of that time were rather controversial. This controversy was expressed first of all by Smiglecki's ideas via his readiness to evaluate economic phenomena on grounds of norms. However, Smiglecki stands apart from representatives of traditional scholastic thought because of his attempt to base his statements on economic criteria. By the consistency of his ideas and analysis of phenomena he excels not only many of his contemporaries, but also many later theorists.

In the preface to his book, Smiglecki pointed out the reason for which he had written such a study, namely 'common need' (he meant traders, craftsmen, and property owners, who needed this type of reference book). Numerous examples in the book taken from local and foreign practice and the economic life of Vilnius represented various kinds of trade contracts. In economics Smiglecki supported the opinion, already approved by canon law, that interest in capital investments (ratio capitalis) was acceptable, while in consumer credit (ratio mutui) it was regarded as groundless and inadmissible.

The issue of money interest in the sixteenth century was widely discussed all over Europe. Forced by developing trade and loan capital, the canonists revised the Church's prohibition on charging interest. Although officially the Church had not yet ceased to declare the 'sinfulness' of usury (in 1568 Pope Sixtus V forbade the agreements on a warranted stable annual interest rate), in practice this prohibition was neglected and even denied by Jesuits themselves. For instance, Doctor Navarrus, a prominent representative of the Salamanca school, regarded such contracts as acceptable. Smiglecki took the same position.

${ }^{6} \mathrm{M}$. Smiglecki, O lichwie i trzech przedniejszych kontraktach: wyderkowym, czynszowym y towarzystwa kupieckiego. Nauka krotka (Vilnius, 1596). The book went through several editions; here we quote from the last edition: Nauka krotka. O lichwie, y o wyderkach, czynszach, spolnych zarobkach, naymach, arendach, y samokupstwie (Vilnius, 1753). 
Smiglecki tried to consider various cases when charging interest on loans can be justified. To these, he ascribed the rent of one's property as one of the most honest ways to make profit, participation in tradesmen's transactions, trade itself, etc. Various casuistic methods were in practice, aimed at justifying virtually any type of charging money interest. For example, if the creditor could be able to make his profit of his own money, but a friend or somebody else wanted to borrow from him (irrespectively of the purpose for which money was borrowed), taking money interest was justifiable. Also, an emolument should not be regarded as usury if the creditor of his own free will gives in charity or guided by an incentive to help his fellowman. ${ }^{7}$ The author's indignation against high interest rates (ten percent and higher) taken by Vilnius artisan fraternities 'which is nothing else but usury' 8 shows him to condemn not the interest itself, but the high percentages.

By the way, regarding the maturity of economic thought, the issue of money interest was perhaps the highest compromise between economic approaches and canonical law and Smiglecki was the most halfway on this issue. In his turn, in his considerations of usury the author was creative and based himself on local examples, without merely repeating the ideas of recognized authorities, which was often the case in his time.

Many of the other economic categories were connected by Smiglecki with factors of demand and supply, as regards prices in particular. In his opinion, the 'just' price is no more than one, which would allow the producer belonging to a definite social stratum to make a moderate living. According to Smiglecki, the 'just' price requires no limitations, no taxes, no monopolies, i.e. the conditions of free competition, a complete freedom of trade, with equal conditions of trading for all. His attitude towards trade monopolies was negative, as they lead to market restriction and rising prices, no matter who owns them - noblemen or merchants. It is not only consumers but also those ousted from trade who suffer because of merchants' monopolies. He objected sharply to noblemen who in their towns enjoyed monopoly rights to producing and selling beer and wine and forced their dependents to buy salt and other goods from them at boosted prices. ${ }^{9}$

\footnotetext{
${ }^{7}$ Smiglecki, Nauka, p. 122.

${ }^{8}$ Ibid., p. 97.

${ }^{9}$ Ibid., pp. $160-162$.
} 
As far as the issue of interest charged on money interest is concerned, the author's position was often dictated by moral criteria, while in the issues of trade his approach was often close to that of classical economic thinkers of the modern times.

Of particular value are Smiglecki's discourses on the economic relations between peasants and landlords. Late in the sixteenth century, with serfdom having consolidated its position, and the simultaneous development of trade and relations with Western European countries, the plight of peasantry was the subject of very wide discussion.

It was impossible to provide conditions for the development of the commodity market without solving the problem of the personal freedom of peasants. Economic supply was in each case bound by feudal limitations, which were an obstacle to the productive development of economic thought. This issue was the focus of attention for numerous advanced authors of the time. Smiglecki in this respect arises not only as a thinker who gave this problem a deep analysis and offered the most constructive criticism of the status of peasants in Poland-Lithuania; he was also the first to make an attempt to show the actual exploitation of peasantry from the economic standpoint.

The author proposed to give personal liberty to peasants. He believed that relations between landlord and peasant should be based on the principle of hiring, but not personal dependence, that is on a certain mutual agreement. Smiglecki recognized the peasant's right to property acquired by personal labour and negated the landlord's right to expropriate it. The author calculated that if the landlord would take the peasant's land, cattle and buildings into his own economy, he would be unable to gain from them the profit he demanded from the peasant. Such exploitation was illegal and based on oppression on the landlord's side. No agreement between the landlord and the peasant should be concluded 'for ever', but only for a certain period of time. In case the objective conditions change, the landlord had the right to reconsider the terms of the agreement; it could be, first at all, an increase of land price, which in turn implied and increased payment, namely the number of bondage days. ${ }^{10}$ This was an attempt to trace back the economic basis on which serfdom grew up to the very cause of serfdom, which he located in the feudal ownership of land. His ideas were destructive

${ }^{10}$ Ibid., p. 118. 
as regards the system of serfdom. Smiglecki endowed the peasant with the right to break his agreement with the landlord (albeit with some stipulations), and this was one of the most progressive points in Smiglecki's suggestions.

As we shall see later, the programme for improving the status of the peasantry, proposed at the turn of the eighteenth and nineteenth centuries by Lithuanian physiocratic ideologists, was even more moderate than the ideas Smiglecki advanced late in the sixteenth century.

Of undoubted value was the economic treatise [The Lithuanian's Approach to a Cheaper Purchase and More Expensive Selling of Corn ${ }^{11}$ written in 1595 by Abramowicz (d. 1602). He was an ideologist of the Reformation in Lithuania, one of the leaders of Calvinism (late in the sixteenth century he established a Calvinist community on his estate in the Vilnius palatinate). The treatise as such was lost. The main five theses of this work were reproduced by the Polish historian Tadeusz Czacki in the nineteenth century, ${ }^{12}$ and even they show the sagacious and innovatory approach taken by Abramowicz to economic issues.

Calvinist economic views were more radical than those of the Lutherans, and they broadcast the seeds of capitalism widely. Their ideas were already devoid of scholastic bonds. Abramowicz, in his analysis of the mechanism of price formation in the market, undertook to elucidate the functioning of the objective factors of the market, which did not depend on human will. He completely rejected the category of 'just price' and formulated the notion of 'natural price', which formed in the market in the absence of monopolies (Thesis 3).

However, the author did not limit himself to understanding the price as the result of demand and supply variations and noted that irrespectively of a high supply of goods in the market (e.g. corn) its price could not fall below the level when production conditions were hardest. Thus he came close to the objective basis of understanding the essence of the price and production costs.

${ }^{11}$ J. Abramowicz. Zdanie Litwina o kupczy taniej zboza, o drogiej sprzedaz [1595], K. Estreicher, Bibliografia Polska: Stolecie XV-XVIII, vol.1, part 3 (Cracow, 1891), p. 8.

12 T. Czacki, O litewskich i polskich prawach, o ich duchu, źródłach, zwiazku $i$ rzeczach zawartych $w$ pierwszym statucie dla Litwy, 1529 roku wydanym, vol.1 (Cracow, 1861), pp. 346-347. 
Similar ideas were elaborated in France by Richard Cantillon later in the eighteenth century in an attempt to understand the cost of goods. However, in the late sixteenth century Abramowicz illustrated the insufficiency of demand and supply theory, as he advanced the idea of expenditure of labour as the basis of the cost of goods (Thesis 3) actually more comprehensively than Cantillon. Czacki highly appreciated Abramowicz's ideas and regarded them as worthy even of Adam Smith.

In his basic statements Abramowicz denied the principles of mercantilism popular in his time (also in Lithuania) and declared a novel approach to economic phenomena. He was a staunch supporter of free trade. By the way, the thesis of free trade itself did not imply a negation of mercantilism. For example, this could be a late mercantilist approach, when objections were expressed not to monopolistic trade companies but to banning the export of money from the country. In this case, the slogan of free trade did not mean elimination of state-imposed restrictions, privileges and of the whole economic policy of mercantilism. However, as a supporter of free trade, he opposed exactly the regulation of both home and foreign trade. Abramowicz was against price taxation and regarded it as an obstacle to trade development (Thesis 4). Therefore we have all reasons to believe that he regarded as inexpedient any intervention to the market. Besides, he thought that those who bought cheaper and sold dearer did no harm to the state and even served it, since otherwise foreign traders would be eager to fill in this gap in the supply. The author was of the opinion that the profit could be higher if we bought corn in our own country (Thesis 2).

The physiocrats maintained also that low prices for raw materials were not profitable for the country. In their opinion, expensive bread was good for all layers of society, as it increased the farmers' profit, which in turn resulted in growing profits of the owners, higher taxes and thus the prospering state. Abramowicz did not develop his ideas (or rather Czacki presented no more or less extensive comments), but we can deduce that in this issue he stood on the positions of the future physiocrats. Just like Cantillon in France, who had advanced similar ideas long before the physiocrats came onto the stage, Abramowicz in Lithuania with his economic views was a kind of predecessor of physiocracy.

Mercantilists believed that in international relations the economic interests of different states disagreed. The economic policy of 
mercantilism was aggressive also within the country (fighting of separate private owners with monopolies, regulations imposed on trade activities, etc.); besides, it was a hindrance to the development of agriculture. It is these features that became prominent in the second half of the sixteenth century in the economic policy of landlords when they subdued all trade in the country to the narrow interests of their own estate and used the most cruel forms of feudal exploitation to this end. This might be the reason for a certain, though perhaps too premature, opposition to mercantilism, which arose in Lithuania. On the other hand, in their desire to purify the Church from corruption, the reformers relied upon the ideals of Early Christianity, whose partisans were far distant from the fiscal interests and the spirit of enrichment, which dominated the economic policy of landlords openly at that time. Calvinist ideology in Lithuania paved the road for a new world outlook, not limited by mercantilist ideals.

Andrius Volanas (1530-1610) was one of the most prominent ideologists of Calvinism in Lithuania. He expressed his economic views in his discourses on various social problems. The widest scope of his economic ideas was presented in the treatise [On Political and Civil Freedom], ${ }^{13}$ as well as in his address to the Riga city commissioners on 12 September 1599. ${ }^{14}$

Volanas regarded liberty as the most valuable thing not only for an individual, but also for the entire society and state. He understood the latter to be the legal defence of the personal and property interests of all members of society, independently of their social origin. In his opinion, a society of universal welfare should be based on freedom.

The concept of 'universal welfare' was very popular in the works of European publicists, including British Reformers. The latter contributed much to changing the content of the concepts inherited from the Middle Ages; for example, self-interest, regarded by the Church as a mortal sin, was explained by British Reformers to be an incentive for 'universal welfare', which was not only inborn in

${ }^{13}$ A. Volanus, De libertate politica civili libellus lectu non indignus (Cracow, 1572). In 1606 this book was translated into Polish by S. Dubingowicz. Here we quote according to the last edition: A. Wolan, $O$ wolności Rzeczypospolitej albo Szlacheckej (Cracow, 1859).

14 Oratio ad Ill. Dominos Comissarios civitatis Rigensis habita a viro clarissimo Andrea Volano oratore eximo (Rigae, 12 Septembris 1599). Lithuanian in Lukšaite, Lietuvos publicistai valstiečiu klausimu, pp. 130-142. 
man, but also stimulated him to increase his wealth and thus the wealth of the whole kingdom. The British Reformers went hand in hand with British mercantilists. Volanas harshly criticised the landlords' striving for wealth, and their avidity as things that opposed social interests. ${ }^{15}$ He tried to propagate bourgeois principles, based on natural law, and the free economic development of both the individual and the state. In his opinion, the main task of the state was to secure freedom and equality to all members of society: equal payment for equal work, equal punishment for equal crime. ${ }^{16}$ According to Volanas, the task of the law in property relations was to guarantee the conditions that would allow an individual to determine 'what is one's own and what belongs to other people'. ${ }^{17}$ He agreed with Calvin, who declared any form of common wealth to be nonsense equal to another extreme - misappropriation and the Church's fraud with regard to the poor. ${ }^{18}$ In comparison with Aristotle, Volanas significantly broadened the concept of 'universal welfare', because the classical philosopher had limited it to the interests of slave-owners and even disregarded farmers, merchants and craftsmen as constituent parts of the state. In Volanas' words, justice should be based on the principle of natural order: not to do harm to anyone, to give each what belongs to him. ${ }^{19}$ Thus, he actually defended the bourgeois law of private property and expressed the well-known principle of free hiring of labour.

Under conditions of increasing feudal exploitation, raising the bourgeois principle of freedom was a significant step in the development of economic thought. However, Volanas did not see any possibility of implementing his principles in Lithuania in his day: he did not demand complete abolishment of serfdom. Thus, Volanas did not escape a paradoxical controversy: he could not completely detach himself from the feudal epoch, but he believed in the ultimate principles of bourgeois freedom.

Volanas' ideas of the society's distribution into estates and their interrelations are very interesting. He rejected the principle of hierarchical juridical subordination and divided society into three main

${ }^{15}$ Wolan, $O$ wolności, pp. 35, 67.

${ }^{16}$ Ibid., p. 18.

${ }^{17}$ Ibid., p. 51.

18 R. Vipper, Tserkov' $i$ gosudarstvo $v$ Zheneve XVI veka $v$ epochu kalvinizma (Moscow, 1894), p. 103.

${ }^{19}$ Wolan, $O$ wolności, p. 19 
estates of noblemen, townsfolk and peasants, showing quite a different approach to each part of society. He rejected the separate estates of the king and the knights and was the pioneer among Polish and Lithuanian authors to reject the clerical estate as making no contribution of social utility to the commonweal. Thus, we see that in Volanas' understanding, 'universal welfare' meant first of all guaranteed favourable material conditions for all members of society, whereas the nobility should share various functions of intellectual activities. Besides, Volanas believed that nobility should comprise the wisest and the noblest people capable of ruling the country and caring for its security. Following the Polish writer Frycz Andrzej Modrzewski, Volanas thought that it was not descent but personal qualities and abilities that should determine an individual's social status. For instance, if a nobleman did not exhibit the properties worthy of his position, he should be transferred to a lower estate, also, a nobleman should not engage in handicraft and trade. ${ }^{20}$

Social estates were regarded by Volanas as partners, and he appreciated the functions of every estate in society equally highly. He wrote:

There are noblemen, townspeople and peasants, all differing in their occupation, mode of life and rights. As noblemen do not engage in any kind of forced or manual labour, they are trained in the art of war, defend the motherland from enemies, and establish the general order. Townsmen engage in trade, bring the necessary things from beyond, train in arts, and thus serve the common welfare, and peasants cultivate the land and provide for all kinds of products. ${ }^{21}$

Volanas emphasised the most essential contribution of peasants into social welfare and the worse legal and economic situation of the estate of peasants. He regarded peasants as the only producers of all material goods ('Whence do all food and clothes, all things of culture and elegance come, whence are our vital needs satisfied, if not from the labour of peasants?'.22) Volanas was approaching the economic position that was later taken by physiocrats. Acknowledgement of productive labour only in agriculture was also a feature of traditional teaching, however, canonists did not need an economic basis for their views. Similar ideas in France, long before the

${ }^{20}$ Ibid., p. 20.

${ }^{21}$ Ibid., p. 33.

${ }^{22}$ Ibid., p. 129. 
physiocrats, were advanced by Sebastien Le Prestre Vauban, Richard Cantillon, and Pierre Le Pesant Boisguillebert.

Let us recollect that in France the economic theory of physiocrats was born in the eighteenth century first of all as a response to the hard situation in the country's agriculture, as an opposition to the compulsory mercantile measures of Jean-Baptiste Colbert, which brought the peasantry to complete ruin. As regards agricultural technology, in the eighteenth century France was behind not only Great Britain, but also the German states and in some aspects even Sweden, Russia and other countries. ${ }^{23}$ The hard situation in Lithuania's agriculture in the eighteenth century as well as unsuccessful attempts to develop serfdom manufactures favoured the rapid spread and rooting of the physiocrats' ideology in the country. A kind of opposition to the economic policy, which ruined agriculture, can be found in Lithuania as early as the late-sixteenth century; Volanas belongs to those who laid an emphasis not on the development of trade but on agriculture. For instance, Cantillon, like Volanas, divided society into three main estates, but Cantillon claimed all estates and all inhabitants to live and grow rich thanks to agricultural proprietors, ${ }^{24}$ whereas Volanas was of the opinion that peasants were the main and only producers of all material wealth. Thus, many of the physiocrats' statements can be found in the works of their predecessors not only in France, but also in Lithuania, where the development of economic thought was much more limited.

Nevertheless, one of Volanas' undoubted merits was his attempt to find economical grounds for differentiating society into estates. Of course, the distribution of society into three main classes (land owners, peasants and all others engaged in activities not related to agriculture) by Quesnay, the patron of physiocrats, was not the crucial point in their economic teaching. However, an analogous approach to the structure of society presented in Lithuania in the sixteenth century by Volanas, whose approach to the country's economy was rather that of a politician than an economist, meant a kind of 'harmony of class interests'. And again associations with physiocrats come to mind. Joseph Schumpeter was right to say that Quesnay proclaimed a universal harmony of class interests, and this

23 S. Rozenberg, Merkantilizm i sotsial'no-ekonomicheskie osnovy fiziokraticheskoi sistemy (Irkutsk, 1927), p. 49.

${ }^{24}$ Ibid., p. 67. 
makes him the predecessor of the nineteenth-century harmonism (Jean-Baptiste Say, Henry Carey).

The manifestation of mercantilist ideas is very important with regard to the development of economic theories, as mercantilism is the first economic theory of a national economy (the state) and a school of political economy as a science. The policy of early mercantilism became especially clearly manifested in Lithuania in the reign of King Sigismund Augustus (1529-1572), however, it did not develop into late mercantilism as was the case in West European countries. The formation of capitalism in Lithuania was actually undermined by the hide reform (valakas or hide, an area of land approximately equal to $20 \mathrm{ha}$ ), which favoured the strengthening of serfdom and met the economic interests of landlords.

It seems appropriate to highlight here some aspects of mercantilist ideology, as we often encounter them while evaluating economic views. Some ideas of mercantilists had been long before expressed by various authors, including representatives of canonic science. However, the development of mercantilism was accompanied by the strengthening of the national state, predominance of secular views in the evaluation of economic activities, rejection of the declaration of moral principles and the prevalence of economic profit as the leading motive. The features of state economic policy, such as stimulation of trade, attempts to accumulate in the country as much of precious metals as possible and the strengthening of armed forces are present in numerous countries at any time. However, an attempt to identify the wealth of a state as an abundance of money (in the form of precious metals) in the country and an emphasis on trade over the other spheres of economy, are signs of mercantilism. Merchants had been guided by such principles from time immemorial, but until modern times both the prevailing standards of society and literature kept condemning such views. Mercantilists were actually the first to break relations with religion and its philosophy. They tried to ground their teaching only on the practice of economic life. Therefore their works were most often polemical and self-justificatory and written by representatives of commercial activities themselves.

One of the works to declare ideas of early mercantilism was the book [On the Customs of the Tatars, Lithuanians and Muscovites] ${ }^{25}$

${ }^{25}$ Michalonis Lituani, De moribus tartarorum, lituanorum et moschorum (Basel, 1615). Text with Lithuanian translation: Mykolas Lietuvis. Apie totoriu, lietuviu ir maskvenu papročius, (Vilnius, 1966). 
written by Michalo Lituanus in about 1550 and published only in 1615 in Basel. The author raised the idea of a strong centralized power, the necessity to strengthen the military power and gave much criticism to the luxurious consumption practiced by noblemen. Of significance is the Michalo Lituanus' idea of changes in taxation. The author suggested that noblemen who in that period were released from taxes (the whole burden of taxes was laid on peasants and townsmen) should be taxed depending on the land they owned. ${ }^{26}$ This was quite a novel suggestion for that period. All theses of the author were based on the pragmatic motives of strengthening the national state.

In the seventeenth century price rises were already out of control. Sejm decisions to fix the prices (in 1613, 1621, 1623) did not improve the situation and only restricted the merchants' interests. Massive signs of the townsmen's discontent appeared. The 'Instruction issued in 1621 to the gentlemen envoys of the City of Vilnius to be handed to Their Graces the Senators on the issue of the ills of this city' 27 also shows the economic views of mercantilism spreading in Lithuania. The complaint contained 15 items, in which the most urgent problems of merchants and townsfolk were explained, and the criticism of the noblemen's economic policy, which was ruining the merchants, was based on the arguments of mercantilist ideas.

A book bearing the title [A Review on Expenditures within and beyond the Crown, when everyone can see like in a mirror the merchants' ruses and huge profits, plunder and usury, as well as various ways how to escape this and to restrain them] is of particular value. $^{28}$ Its author and the place of printing are not yet definitely known. Polish historians ascribe it to Stanisław Zaremba. ${ }^{29}$ In our opinion, the treatise should be regarded as anonymous. It is significant for the economic thought of both Lithuania and Poland as a

${ }^{26}$ M. Lietuvis, Apie totoriu, pp. 52-53.

${ }^{27}$ Instrukcya panom poslom miasta Wileńskiego do Ich Mciów panów senatorów dana w sprawie miasta tego doległości w roku 1621, Kwatralnik Historyczny, 7 (1893), pp. 442-446.

28 Okuliary na rozchody $w$ Koronie $i$ z Korony, przez ktore jako $w$ zwierciadle obaczyć każdy może fortele $i$ nieznosne zyski, zdierstwa a lupiestwa kupieckie. Przy tym srzodki i sposoby różne jako temu zabiezeć i one pohamowac (1623).

${ }^{29}$ Historia nauki polskiej, vol. 6 (Wroclaw, 1974), p. 780. 
mature reflection of late mercantilist ideas. It contained criticism of both noblemen's and merchants' policy, in an attempt to show how noblemen could render profitable to the whole country commerce which was serving only the narrow interests of their social estate. The profuse discussions among Lithuanian-Polish and Prussian noblemen (the treatise is written in the form of dialogue popular at that time) reflect the main economic problems of the country of the first half of the seventeenth century: rising prices, worsening of money (reduction of coins), restricted rights of townsmen, and the expanding license of the nobility.

First of all the author presents a wise assessment of the situation, which was disastrous for the country, when in exchange for various industrial products and particularly for luxury items the country would lose huge sums of money. The export of various agricultural products from Lithuania and Poland to Western countries was comparatively cheap. The author even tried to calculate the difference between the costs of imported and exported goods. He gave a vivid characterisation and formulation of the passive balance of trade and pointed out the much larger import to be the main cause of the economic problems of the country, especially that there was no necessity for such a disadvantageous trade when foreigners brought in and sold for highest prices items of luxury which could be easily dispensed with. The author's motives are based mostly on mercantilist arguments: the propaganda of thrift and economy, accumulation of gold and silver within the country. Moreover, the ways are suggested how to make the mercantile principles practicable and working. Although not rejecting a strict regulation of trade, the author was fully aware of its insufficiency. For the first time in the literature of that time a constructive rearrangement of state economic policy was suggested. Therefore some postulates of early mercantilism were neglected, and the author proposed to develop and stimulate various ways of industrial production in the Polish-Lithuanian state.

In dialogue form the Prussian noblemen express the author's ideas how unprofitable it is to export to German lands wool and flax as a raw and then import fabrics from there. A German himself said that it was 'sheer ignorance as you pay us hundredfold and give us back what we have given you for the same materials'. ${ }^{30}$ Worth

${ }^{30}$ Okuliary, p. 50. 
noting too is the proposal made by the author to produce goods not only from local raw materials, but also follow the example of the Netherlands which imported raw materials for its industry even from India. This proposal was revolutionary not only in the Polish-Lithuanian state, but also in the countries in which industry was already in the process of development.

This kind of suggestion was formulated in print for the first time by the English trader and writer, Thomas Mun (1621), and this is regarded as the beginning of a new period (late mercantilism) in the development of the mercantilist economic conception. Mun was the first to come out against banning the export of money, which was a measure that hampered the development of trade. He claimed the active balance of trade to be the best way for increasing national wealth. Our author was also in favour of this approach. We do not know whether Mun's work was known to him (Okuliary was published only a couple of years later) or the author came to this conclusion by himself upon analysing the economic practice of the Western countries. He was fully aware of the fact that serfdom was the main obstacle for this economic policy to develop. Therefore he demanded first of all to expand the rights of peasants and townspeople. The book contains also ideas of free managing and points out that the presence of competition would stimulate the better quality of products. ${ }^{31}$ We can see that these suggestions popularised the ideology of the arising bourgeoisie, but this work is of particular value also because having reached the top level of the then economic thought, at the same time it managed to disclose the deep-rooted reasons for the economic situation in the PolishLithuanian state.

The economic decline of the country in the second half of the seventeenth century was greatly and mostly influenced by the nobility's economic policy: the restricted rights of townspeople and the burden of taxes (including hide taxes paid by peasants) imposed on them limited greatly their economic activities. At the same time, fighting for townsmen's interests in the Sejm was practically impossible; as only representatives of the capital city could take part in its sessions. The price taxation policy, pursued by noblemen, unfortunately could not stop the process of inflation, led to the closure of most of the trading spots, and the mid-seventeenth century saw an obvious decline in trade. 
The falling prices of corn and the rising prices of industrial goods and luxury items in Western Europe resulted in the passive balance of trade in both Poland and Lithuania. In the LithuaniaGdańsk-Holland trading chain through which agricultural products and timber were moving from Lithuania, it was not the countriessuppliers but the foreign agents making transactions that were making profit, too. The unfavourable trading conditions lead to an economic decline, in the first place of the owners of moderate estates, who could not compensate for the decline of the purchasing power of their products by intensifying exploitation of peasants.

A way out of the grave economic situation could be found only in reorganising the very structure of production, however, even in the first half of the seventeenth century the economic forces that could undertake such a task were practically absent: the conditions for a middle class to develop were undermined, the landlords strengthened their positions by intensifying their exploitation of peasants and ruining townspeople.

Wars with Muscovy and Sweden in the second half of the seventeenth century brought about huge losses to the country. The economic disturbance was enhanced by yet higher prices and the monetary crisis: in 1659-1666, when instead of silver coins, copper ones were introduced. The devastating Great (or Third) Northern War (1700-1721) caused severe losses to people and property in Lithuania. It was only the end of the seventeenth century that saw a more or less pronounced restoration of peasants' estates, but this was not accompanied by tangible economic changes in the countryside or the towns.

Thus it was in the sixteenth century that Lithuanian economics entered the period of development when the feudal relations of production were modified in order to adapt to the developing commodity economy, which had to be followed by primary accumulation of capital. This was the function, which the nobility failed to perform, turning the means gained through trade into a source of luxurious private consumption, and the class of townspeople still was too weak. Transition from feudalism to capitalism in Lithuania was not only painful (the 'second round' of serfdom came, when the nobility used the increased demand of agricultural products in the West as the reason for introducing a more severe regime of serfdom), but also prolonged because of the specific political circumstances. All these facts were also of crucial significance for the 
manifestation of economic thought in Lithuania, its obvious rise in the late sixteenth century and its subsequent long period of stagnation.

Both the Jesuits and the Protestants undoubtedly contributed to the development of economic thought in Lithuania. However, the Jesuits' attempts to be progressive in economic issues in Lithuania vanished with the final victory of the Counter-Reformation (in the first half of seventeenth century). The canons of economic thought returned to its medieval framework and actually defended much more conservative views than it had a century before. The theses that have survived from the end of the seventeenth century in fact strictly follow the economic views of Aristotle, and the state system of Poland-Lithuania received more praise than criticism. ${ }^{32}$

In 1773 the Society of Jesus was suppressed, and the Vilnius Academy was placed under the control of the Educational Commission. The system of education underwent reorganisation, and a course of natural law was introduced at the College (Faculty) of Morals established in 1781. The first professor to teach this course was Hieronim Stroynowski (1752-1815), who was the first in the world to teach this academic discipline on the basis of the economic theory of physiocracy in 1783-1793. This course found reflection in his book [The science of natural, political law, political economy and the law of nations] (published in 1785). ${ }^{33}$ It became a widely recognised handbook of natural law (five editions were published); in 1809 it was issued in St Petersburg in Russian.

The Educational Commission even included lessons on physiocratic theory in the curriculum of secondary schools. Interestingly, the well-known poet Adam Mickiewicz, while teaching in one of the secondary schools of Kaunas, alongside other disciplines taught also political economy on the basis of Stroynowski's book. A similar course in natural law was for several years taught also at the University of Cracow by the Polish physiocrat A. Poplawski. However, nowhere in Europe was physiocratic theory recognised as widely as it was in Lithuania. At that period, the as yet obscure Swiss economist Jean-Charles Sismondi presented an opus in an attempt to get a professorship at the Political Economy Department of Vilnius University. In his essay Sismondi already defended Adam

${ }^{32}$ E. Laumenskaite, Ekonomine mintis., pp. 71-80.

${ }^{33}$ H. Stroynowski, Nauka prawa przyrodzonego, politycznego, ekonomiki politycznej i prawa narodów (Vilnius, 1785). 
Smith's economic views, and perhaps this was the reason why his candidature was rejected. Stroynowski, rector of Vilnius University at that time, could not be satisfied with such an outlook from a future professor. Thus, the very personality of Stroynowski, his influence in the higher school were very significant, and the economic science in Lithuania based on physiocratic economic ideas acquired the direction of an economic theory and not of narrowsighted cameralism, as was the case in most universities; for instance, at Dorpat University, instead of the Department of Political Economy the Department of Cameralism was established; similar tendencies were obvious at Moscow University, and cameralism was already deep-rooted at German universities.

As mentioned above, Stroynowski began teaching the course of natural law in 1783. Wide discussions on economic problems in this discipline contributed to political economy's becoming an independent discipline at Vilnius University sooner than in other higher educational institutions. In 1803, political economy was singled out from the general course of natural law and legitimated as an independent discipline. This fact is of significance not only for the history of Lithuanian science; it was the first time that political economy was established in the curriculum of an institute of higher education as an independent academic discipline. It is a known fact that the then rector, Stroynowski, took an active part in elaborating the new Statutes of the University of Vilnius, as in 1803, by the order of Tsar Alexander I the Principal School of the Grand Duchy of Lithuania was renamed into the Imperial University; 34 a new statute was approved and the basic disciplines were revised. Somewhat later, political economy departments were established also at other universities where the course of the fundamentals of economics was sometimes delivered within the framework of moral philosophy. Economic sciences began to be taught at the University of Moscow early in the nineteenth century, but physiocratic theory was not popular. There, Smith's economic theory began to spread, thus in the short run also Vilnius University had to accept it. In this case, this was a progressive move towards theoretical knowledge and the students gained the chance to become better acquainted with various economic theories. This is why the course of political economy delivered later at Vilnius University contained also a rather broad

${ }^{34}$ In 1795 the Grand Duchy of Lithuania was incorporated fully into the Russian Empire. 
historical overview of the development of economic theories. In the third decade of the nineteenth century the course of political economy was taught by Jan Waszkewicz (1797-1859); it covered the ideas from Xenophon, Ptolemy, and Aristotle right up to the works of the early nineteenth century.

Thus, late in the eighteenth and early nineteenth century under the shelter of Vilnius University, an atmosphere of economic training was formed in Lithuania, fundamental economic theories were taught, scrutinised, and interpreted. Both Stroynowski, who taught physiocratic theory, and Waszkewicz, who lectured on Smith's economic views, tried to accommodate these ideas to the local conditions, debated and even eliminated some elements of these teachings, which in their opinion were unacceptable here. This tendency is pronounced also in their own works.

In the above-mentioned popular work by Stroynowski some elements of physiocratic teaching were treated somewhat differently. In the second half of the eighteenth century. the economic development of France provided conditions for physiocratic scientific theory to appear, while Poland-Lithuania still lacked such a basis. Some of the categories presented in Quesnay's system could even appear not quite clear here. Therefore Stroynowski simplified the treatment of economic categories and rejected the analysis of some economic phenomena (for example, he left aside the loan capital, pay problems). In his turn, Stroynowski creatively developed some of Quesnay's ideas and harmonised them with Lithuanian conditions, especially the issues of power, which occupied a very important place in physiocratic theory.

Quesnay was a supporter of absolute monarchy and gave a rather extensive substantiation of his position, disclosing the narrowminded, selfish interests of all strata of society. As he put it, the supreme power is best to meet the requirements of the natural order: it is an educated absolute monarch (not a despot), well acquainted with the laws of the natural order, independent of various private interests and capable of reforming the society from above (by his philosophical views Quesnay belonged to the French Enlightenment). Stroynowski accepted the principle of the independence of power of any private interests, but never expressed support for absolute monarchy. He emphasised that the specific living conditions of every nation predetermine the form and structure of its government. Whoever exercises power - one person or a body consisting of a 
definite number of persons - they ought to base themselves on principles, which do not contradict natural order, and the mutual duties and rights of nation and the supreme power that follow from the natural order. ${ }^{35}$ Besides, these rights and duties ought to be legalised by law and made known to the whole nation.

Stroynowski harshly criticised the impotence of the powers that governed the Commonwealth in his day and gentry anarchy, and stood for the constitutional order. In this way he expressed the position of progressive noblemen, who were stirring issues of reform needed by the country.

Serfdom seemed to Stroynowski unacceptable in principle: more than once he accentuated the similar nature of every man and the equal rights to personal and private property. However, the criticism of serfdom in Stroynowski's book was of a purely ethic nature, academic, and devoid of specific demands. As a theologian, in this respect he was limited to ethic criteria and criticism. His brother Walery Stroynowski's work [On Landlords' Contracts with Peasants $]^{36}$ (1808) contained already more strictly formulated demands: the author proposed to let land to peasants for a labour rent; however, he did not yet approve of the free migration of peasants. All that Walery Stroynowski demanded was to allow the peasant to let his plot to another person.

A comparison of Smiglecki's and Stroynowski's ideas regarding the personal liberties of peasants shows that late in the sixteenth century Smiglecki's demands were more radical, and if implemented they could have provided more favourable conditions for hired labour to develop. Nevertheless, even the moderate proposals by Stroynowski and his criticism of serfdom in Lithuania in the late eighteenth and early nineteenth centuries were a progressive phenomenon.

In this period of an upswing of economic thought in Lithuania, alongside Stroynowski two more names are worth mentioning. By their works and particularly academic activities they contributed most significantly to the development and spreading of economic science. One of them has been mentioned already, namely Waszkewicz, who taught political economy in 1824-1832 and advocated mostly the fundamentals of Adam Smith. The other name

${ }^{35}$ Ibid., p. 153.

${ }^{36}$ W. Stroynowski, O ugodach dziedziców z włosciami (Vilnius, 1808). 
is that of Michał Oczapowski (1788-1854) who taught agricultural disciplines at Vilnius University from 1822 up to its closure a decade later. Oczapowski can be regarded as the founder of land economy in Lithuania. In his papers and particularly in his lectures he widely discussed the situation in Lithuanian agriculture and ways to improve it; he was a staunch supporter of reforms in serfdom economy.

Oczapowski wanted to convince the landlords that hired work is profitable not only to a worker but also to the land owner; he tried to demonstrate the inefficiency of serfdom economy based on noneconomic exploitation, and used the categories of capitalist economy in his arguments. ${ }^{37}$ His particularly high merit is that when teaching various agricultural disciplines (new principles of organisation in agriculture and the economy, income and expenditure accounting in agriculture) he elucidated the relationship between various branches of economy and general theory of economics, related the general issues of economics with the country's specific social economic conditions. Oczapowski mostly popularised rational agricultural practice, as witnessed by him while working in Germany at the Mögellin experimental agricultural estate headed by Albrecht Thaer.

The rise of economic life at the end of the eighteenth century, despite great political disturbances, provided for an environment of radical economic reforms. The law, passed in 1791, allowing the landlords to engage in trade implied the downfall of the old approach to the social status of landlords. There were open demands to emancipate serfs (as in 1817 in the session of the Vilnius Palatinate Nobility Dietine) and urges to invest in industry and concentrate on the development of production and trade. These in turn were the factors that stimulated the spread of Smith's ideas.

Quesnay's system reached Lithuania directly from France in a rather pure form, whereas Smith's theory spread here in a somewhat modified version. Its popularisation in Lithuania began in the period when in the West numerous economists were already revising Smith's arguments. Besides, at that time the ideas of David Ricardo, JeanBaptiste Say and Thomas Robert Malthus were already popular.

Waszkewicz, while appreciating Smith's economic views highly, disagreed on some issues with the renowned economist and even pointed out the lack of systemisation in his Wealth of Nations.

${ }^{37}$ M. Oczapowski, O nauce gospodarstwa wieyskiego $w$ ogolności (Warsaw, 1834), pp. 95-98. 
The Vilnius professor did not accept Smith's principle that labour is a measure of value. In this respect, he preferred the views of Heinrich Storch who believed that the value of goods depended first of all on their utility. In his papers under the titles ['Theory of civilisation'] and ['On various political economy theories'] Waszkewicz discussed broadly the issues of productive and non-productive labour, again disagreeing with Smith's definitions (he was more in line with the views of Georgius Sartorius and, particularly, those of Storch). In his work Waszkewicz avoided social issues. His interests lay rather in the sphere of economic theory. Waszkewicz's book on the science of trade and his concise history of banks (the latter being a very slim volume) were like textbooks for students as an extension of his course of economic theories on trade and financing issues. ${ }^{38}$ In Lithuania Waszkewicz seems to have thrown a bridge between economic theory and commeralistics; we can say that together with Oczapowski he also introduced the fundamentals of commeralistics at the University of Vilnius.

Thus, the formation and development of economic disciplines at the University in the late eighteenth and early nineteenth centuries favoured an intensive economic enlightenment of Lithuanian society. The Department of Political Economy at Vilnius University turned into a focus of the formation of liberal ideas. These ideas exerted an undoubted effect on the world outlook of the Philomath secret society. It is a known fact that some of its members were preparing themselves for lecturing political economy at the university and were already teaching it at secondary schools. ${ }^{39}$ After suppressing the 1830-1831 insurrection in Lithuania the tsarist government closed also the rebellious university. Thus, economic sciences, which had been deeply rooted in Lithuania, were eliminated.

Further development of economic thought was restricted for almost a century. Only after restoration of the state's independence (1918) and opening of the University of Lithuania (Kaunas, 1922, from 1930 Vytautas the Great University) a new period started in the development of economic science. However, the tasks and problems to be solved for the economic science were already quite different.

38 J. Waszkewicz, Nauka o handlu (Vilnius, 1830); idem, Historia banków oraz innych celniejszych ustanowień kredytowych (Vilnius, 1838).

${ }^{39}$ E. Laumenskaite, 'Ekonomikos mokslų kūrimasis Lietuvoje XVIII-XIX a. sandūroje', Pinigu studijos, 4 (1999), pp. 46-55. 
An obvious feature of the development of economic thought in Lithuania was its uneven evolution, which was connected with the country's general economic and political development. Periods of political and economic upheaval and occupation had a strong impact on cultural processes and determined evident breaks in the development of economic thought in Lithuania. If the economic thought of the two periods under analysis was more influenced by the country's own social and economic conditions, later development of economic thought in the twentieth century would obviously depend more on changes in the country's political status, and every time economic science started to develop as if from scratch. ${ }^{40}$

\section{Author Details}

Dr Egidija Laumenskaite is a senior researcher of the Institute of Economics (Lithuanian Academy of Science). Her main areas of research are history of economic thought in Lithuania, economic history and economic philosophy, and she is author of two books and over 30 articles. She lectures in the history of economic thought, and international economics in Vilnius Management Academy.

Address: LMA Ekonomikos institutas, Goštauto g. 12-319, LT-01108 Vilnius, Lithuania

Email: elaumens@ktl.mii.lt

${ }^{40}$ Within one (the 20th ) century we may observe three separate periods in the development of economic thought in Lithuania: (1) the interwar period, during which the universities of Vilnius (in Poland between 1920 and 1939) and of Kaunas had no links), (2) the Soviet period (from the 1940s up to the 1990s) when economic ideas could be developed only within a Marxist-Leninist framework) and (3) the last decade of the century. All those periods had no continuity of the economic ideas. 
EKONOMINĖS MINTIES VYSTYMOSI YPATYBĖS LIETUVOJE XVI-XIX A.

Santrauka

\section{EGIDIJA LAUMENSKAITE்}

Ekonominès minties raida Lietuvoje pasižymi tam tikromis ypatybėmis, kurios nebuvo būdingos kitoms Europos šalims, nuëjusioms tolygesnị socialinio ir ekonominio vystymosi kelią. Kita vertus, ekonominès minties pakilimo ir nusileidimo laikotarpiai glaudžiai susiję su bendromis socialinès ir kultūrinès raidos ypatybèmis bei Vilniaus universiteto veikla. Tai, kad $1803 \mathrm{~m}$. Vilniaus universitete buvo įkurta pirma pasaulyje Politinės ekonomijos katedra, o fiziokratų ekonominè teorija tapo akademine disciplina, yra išimtinis reiškinys Europos mokslo istorijoje. Fiziokratų teorijos populiarumą Lietuvoje pirmiausia nulèmė socialinès ekonominès krašto sąlygos, o taip pat glaudūs Lietuvos didikų kultūriniai ir asmeniniai ryšiai su Prancūzija bei fiziokratais. Šiame straipsnyje mes taip pat parodome ankstesnio, t.y. pirmojo, ekonominès minties pakilimo laikotarpio Lietuvoje (XVI a. pab. - XVII a. pr.) idèjines sąsajas su fiziokratų pažiūromis. Juo labiau, kad šio laikotarpio ekonominè mintis, nors ir negausi savo darbais, išsiskiria savo ypatingu idejjiniu brandumu Europos ekonominès minties kontekste. Vèlesni ekonominès minties pakilimo laikotarpiai Lietuvoje (XVIII-XIX a. sandūra ir XX a. pirmoji pusé, o taip pat jo paskutinis dešimtmetis) labiau tik seké Vakarų ekonominių idejjų raidą.

Ekonominis Lietuvos pakilimas ir ūkio reformos, aktyvus Reformacijos judejjimas XVI a. viduryje pažadino gana plačią polemiką socialiniais ir ekonominiais klausimais. Tiek Reformacijos, tiek katalikų ideologai (ypač 1579 m. jëzuitų ikurto Vilniaus universiteto dèstytojai) kèlè opias to meto krašto ekonomines problemas. Jono Abramavičiaus, Martyno Smigleckio ir nežinomo autoriaus knygos „Pažvegimas i išlaidas Karūnoje..." ekonominès idèjos savo brandumu neatsiliko nuo to meto europinès ekonominès minties lygio, įsiliejo i pirmujų ekonominių koncepcijų - merkantilizmo ir fiziokratų teorijos - formavimąsi. Švietimo reformos Vilniaus universitete XIX a. pabaigoje atvėrè duris naujų ekonominių disciplinų kūrimui. Profesorių Jeronimo Strojnovskio, Jono Vaškevičiaus, Mykolo Očapovskio akademinè veikla ir ekonominiai darbai padejo atskirų ekonomikos mokslo šakų pagrindus. 1830-1831 m. numalšinus sukilimą Lietuvoje, caro vyriausybė $1832 \mathrm{~m}$. uždarè ir Vilniaus universitetą. Taip buvo beveik šimtmečiui pakirstas ir sustabdytas ekonomikos mokslo vystymasis Lietuvoje.

Ekonominès minties raidai Lietuvoje buvo būdingas ryškus jos vystymosi netolygumas, visiškos stagnacijos ir spartaus pakilimo laikotarpiai, ir kiekvieną kartą ekonominè mintis turejo prisikelti tartum iš naujo. Ši tendencija ir idejinio perimamumo stoka dar ryškiau pasireiškė XX a. bėgyje. 